\title{
Phronesis and spirituality in the workplace
}

\author{
Patricia Grant and Peter McGhee \\ Auckland University of Technology, New Zealand \\ Te Wananga Aronui O Tamaki-Makau-Rau
}

\begin{abstract}
A review of the relevant literature recognised several characteristics that permeate discussions on spirituality. This paper's premise is that these characteristics inform an individual's choice of values - they form a type of regulative ideal. The process developed explains the link between these values and virtue and therefore ethical behaviour in the workplace. The values frameworks developed recently in the spirituality literature specify those things a spiritual person perceives as worth having, getting or doing. This paper contends that these values, particular to spiritual persons, contribute to the flourishing of individuals and therefore lead to the acquisition of virtue. Spiritual persons are likely to be ethical persons. Such individuals are likely to be of significant benefit to their organisations. A process is offered to explain the link between these values, virtue and ethical behaviour in the workplace. Central to this process is the notion of phronesis (practical wisdom) in the perception, selection and implementation of spiritual values in the workplace.

Practical wisdom or phronesis is the reward for striving for virtue. It is the ability to know what is good to do here and now. It enables a person to have rational control of their feelings: to "have those feelings at the right times on the right grounds towards the right people for the right motive and in the right way" (Aristotle, Trans. 1941, NE Bk 2 chap 6; 1106b16). This paper contends that spiritual values, particular to spiritual persons and enhanced through phronesis, contribute to the flourishing of individuals and therefore lead to the acquisition of virtue. Phronesis is essential if espoused organisational values are to become a reality in the life of the organisation.
\end{abstract}

Key Words: Spirituality, virtue ethics, phronesis, regulative ideal, values

\section{INTRODUCTION}

A distinguishing feature of modern society is the extraordinary popularity of spirituality and the proliferation of its use in popular media and by laypeople in a seemingly endless variety of contexts. Businesses today are also increasingly recognising the spiritual nature of human beings as well as the possibilities such individuals embody. Evidence of this exists in the expanding literature (see e.g. Ashmos \& Duchon, 2000; Benefiel, 2005; Giacalone \& Jurkiewicz, 2003b; Kolodinsky, Giacalone \& Jurkiewicz, 2007; Marques, Dhiman \& King, 2007; Mitroff \& Denton, 1999; Smith \& Rayment, 2007). Moreover, the introduction of courses on management and spirituality in universities, special issues of peer-reviewed journals (for example, the Journal of Organizational Change Management Vol.12, No.3 (1999) and Vol.16, No.4 (2003), and the Leadership Quarterly Vol. 16, No. 5 (2005)) and the development of interest groups among the academy (e.g. Academy of Management's (AOM) Management, Spirituality and Religion (MSR) Group) are additional signs of awareness. Indeed, Neal and Biberman (2003) contend that AOM's endorsement has provided substantial "legitimacy and support for research and teaching in this newly emerging field" (p. 363).

Contained within this literature is the notion that spiritual individuals are purportedly ethical in business, and consequently, are of significant benefit to an organisation. Indeed, research to date does provide some evidence of this relationship (Beazley \& Gemmill, 2006; Biberman \& Whitty, 1997; Cash \& Gray, 2000; Giacalone \& Jurkiewicz, 2003a; Giacalone, Paul, \& Jurkiewicz, 2005; Krishnakumar \& Neck, 2002; Mitroff \& Denton, 1999; Neck \& Milliman, 1994; Nur \& Organ, 2006). What is unclear, however, in the spirituality in the workplace (from now on, SWP) literature is why and how an individual's spirituality influences their ethical performance within an organisational context. Building on previous work carried out by Cavanagh \& Bandsuch

Correspondence concerning this article should be addressed to Peter McGhee, Faculty of Business, Auckland University of Technology. email: peter.mcghee@aut.ac.nz 
(2002) and McGhee \& Grant (2008), this paper further develops this process using Aristotelian virtue ethics and the notion of phronesis (practical wisdom) to address this lacuna.

\section{WHAT IS SPIRITUALITY?}

After surveying the literature we offer the following description of spirituality as consisting of four behaviours that evidence a specific mindset.

The behavioural characteristics of spiritual individuals include:

- $\quad$ Seeking to transcend their ego (i.e. their own self-interests)

- Awareness and acceptance of their interconnectedness with others, creation and their Ultimate Concern

- Understanding the higher significance of their actions while seeking to integrate their lives holistically

- Believing in something beyond the material universe which ultimately gives value to all else.

A brief description of each of these follows. According to Ashforth \& Pratt (2003), themes of selftranscendence figure prominently in most definitions of spirituality. What is self-transcendence? It is something that calls us beyond the "self" (i.e. the ego) to concern for, and relationships with, others and with the ultimate "other". Such persons transcend their egoistic self not by floating off to some mystical union or separate realm of existence but by coming to terms with its enlarging and transformative potentiality (Solomon, 2002).

Spiritual persons seek to live an authentic life sourced in meaningful relationships. The process of selftranscendence, of affirming the spirit and transcending the ego, results in a growing awareness and acceptance of interconnectedness with the self, others and one's Ultimate Concern. This also is a general theme in the writing on spirituality (see e.g., Kale, 2004; Lapierre, 1994; Sass, 2000).

The importance of a sense of purpose is also apparent in the spirituality literature (Elkins, Hedstrom, Hughes, Leaf, \& Saunders, 1988; Emmons, 2000; Wink \& Dillion, 2002) Spirituality represents a higher level of understanding that enables the contextualisation of lower levels. It provides answers to the question "why?" and confers individual lives with a sense of integrated wholeness (Mitroff \& Denton, 1999).

Finally, spirituality is the personal expression of an Ultimate Concern. According to Tillich (1952), ultimate concerns are those 'God values' in our lives which have centring power; they are the things with which we are ultimately concerned. The actual content of this belief may vary (e.g. theistic, non-theistic or humanistic); however, whatever the content or models used to describe it, the spiritual person believes in something bigger than themselves (Elkins et al., 1988; Mitroff \& Denton, 1999). As an individual strives for their Ultimate Concern, whatever that may be, they transcend their self-interest, have a growing awareness of the other, and a deeper understanding of one's actions within a broader framework. One's ultimate concern provides the motivation and empowerment to action their spirituality (Nelson, 2009).

Spirituality is the actualisation of an inherently human capacity. Spirituality is about "becoming a person in the fullest sense" (Macquarrie, 1992, p. 40) as one authentically quests for their ultimate value. Spiritual people experience the object of spirituality via their desire to transcend the self, to develop authentic relationships with others and as they strive to find meaning and purpose in their life.

Since the spiritual quest is directed towards the ultimate concern in one's life, spirituality seems to have a direct reference to morality (Downey, 1997), and it is generally accepted in the literature that an appropriate spirituality, that is, one defined by the characteristics discussed above, results in and is demonstrated by virtuous behaviours, and a good life. How might this occur?

\section{Spirituality as a Regulative Ideal}

This paper proposes that a person's spirituality, characterised by the degree they imbue and live out selftranscendence, interconnectedness, a sense of purpose, and a belief in an Ultimate Concern, constitutes a regulative ideal (from now on, RI). Oakley \& Cocking (2001) define the RI as an:

Internalised normative disposition to direct one's actions and alter one's motivation in certain ways. To say that a person has a RI is to say that they have internalised a certain conception of correctness or excellence in such a way that they are able to adjust their motivation and behaviour so that it conforms, or at least does not conflict, with that standard (p. 25). 
For an individual who has internalised a certain conception of what it is to be spiritual, they can be guided by this conception in their practice, through regulating their motivations, perceptions and actions towards others so they are consistent with their notion of spirituality.

According to Oakley \& Cocking (2001), RIs may be general in scope, or they may be specific to certain domains. A general RI produced from the four components listed earlier will govern the spiritual individual's life. However, specific RIs may also guide the activities of a spiritual individual in particular areas. Oakley \& Cocking (2001) also note that since RIs operate as a background guide for our motivation, they direct us to act appropriately, even when we are unaware of them and do not deliberately aim at them. In other words, they can guide us in our actions without becoming one of our purposes in acting.

What might a spiritual person's RI be like? Spirituality is about making sense of one's existence while recognising the interconnectedness of all living things. It involves standing outside ourselves and considering the meaning of our actions, the complexity of our motives and the impact we have on the world around us. Further, it involves seeking a sense of purpose or 'being' and becoming connected to something greater than just one's own ego - a connection that provides a sense of the sacred or the holy. Consequently, a spiritual person's RI will consist of values and principles that will reflect these deeply held understandings.

What happens when we contextualise this individual within the workplace? Such a person understands the need to bring the whole person to work. They want to integrate their lives and in doing so connect with themselves and with others in their workplace community (Dehler \& Welsh, 1994). Spiritual individuals endeavour to "express inner life needs by seeking meaningful work" (Ashmos \& Duchon, 2000, p. 136). They confer their work and the workplace with the quality of connection to something greater than the material world. Work becomes part of a bigger picture; it is a calling, a vocation and not merely a means to an end. As part of this process, spiritual persons subjugate their workplace ego to their Ultimate Concern whatever that may be. Giacalone \& Jurkiewicz (2003b) summarise these ideas in stating that a person with spiritualityoriented ideals "balances economic, quality of work life, and social responsibility concerns" (p. 16).

What might be the core values or principles of a spiritual worker's general RI? The literature has not been reticent in this area. In recent years, a number of publications have discussed the role of spiritual values in the workplace (see Table 1).

Table 1: A comparison of scholarly articles comparing similar values relating to spiritual individuals in the workplace

\begin{tabular}{|l|l|l|}
\hline Author(s) & Spiritual Values & Comment \\
\hline Jackson (1999, pp. 65-66) and & $\begin{array}{l}\text { Equality, Honesty, Compassion, } \\
\text { Avoiding Harm, Respect, Peace, } \\
\text { Justice, Forgiveness, Service, Duty } \\
\text { Trustworthiness, Being a Good } \\
\text { Citizen, Peace, Thankfulness }\end{array}$ & $\begin{array}{l}\text { Spiritual values from world's } \\
\text { main religions (Sikhism, } \\
\text { Buddhism, Judaism, Christianity, } \\
\text { Hinduism, Islam, Baha'ism, } \\
\text { Confucianism and Jainism) }\end{array}$ \\
\hline Synder \& Lopez (1954) & $\begin{array}{l}\text { Optimism, Hope, Humility, } \\
\text { Compassion, Forgiveness, Gratitude, } \\
\text { Love, Altruism, Empathy, Toughness, } \\
\text { Meaningfulness }\end{array}$ & $\begin{array}{l}\text { List of values linked to positive } \\
\text { psychology and spirituality }\end{array}$ \\
\hline $\begin{array}{l}\text { Giacalone \& Jurkiewicz (2003b, } \\
\text { p. 14) }\end{array}$ & $\begin{array}{l}\text { Integrity, Humanism, Awareness, } \\
\text { Meaningfulness, Responsibility, Love, } \\
\text { Inner Peace, Truth, Humility, Sense of } \\
\text { Community, Justice }\end{array}$ & $\begin{array}{l}\text { Manifestations of spirituality in } \\
\text { the form of spiritual attributes }\end{array}$ \\
\hline Fry (2003, p. 695) & $\begin{array}{l}\text { Forgiveness, Kindness, Integrity, } \\
\text { Empathy, Honesty, Patience, } \\
\text { Courage, Trust, Humility, Service to } \\
\text { Others }\end{array}$ & $\begin{array}{l}\text { Specifically tied to spiritual } \\
\text { leadership; all subordinate under } \\
\text { a single value: altruistic love }\end{array}$ \\
\hline $\begin{array}{l}\text { Jurkiewicz \& Giacalone (2004, p. } \\
\text { 131) }\end{array}$ & $\begin{array}{l}\text { Benevolence, Generativity, } \\
\text { Mumanism, Integrity, Justice, } \\
\text { Responsibility, Trust }\end{array}$ & $\begin{array}{l}\text { Values framework for measuring } \\
\text { workplace spirituality }\end{array}$ \\
\hline
\end{tabular}




\begin{tabular}{|l|l|l|}
\hline Fry (2005, p. 56) & $\begin{array}{l}\text { Honesty, Forgiveness, Hope, } \\
\text { Gratitude, Humility, Compassion, } \\
\text { Integrity }\end{array}$ & $\begin{array}{l}\text { A set of core values reflecting a } \\
\text { state of ethical and spiritual well- } \\
\text { being experienced by a spiritual } \\
\text { employee }\end{array}$ \\
\hline Marques (2005, p. 86) & $\begin{array}{l}\text { Respect, Understanding, Openness, } \\
\text { Honesty, Giving, Trust, Kindness, } \\
\text { Peace \& Harmony, Acceptance, } \\
\text { Creativity, Appreciation, Helpfulness }\end{array}$ & $\begin{array}{l}\text { Vital themes for a spiritual } \\
\text { workplace from the literature and } \\
\text { compared with the statements of } \\
\text { six business executives. }\end{array}$ \\
\hline Reave (2005, p. 658) & $\begin{array}{l}\text { Meaningfulness, Integrity, Honesty, } \\
\text { Humility, Respect, Fairness, Caring \& } \\
\text { Concern, Listening, Appreciating } \\
\text { Others, Reflective Practice }\end{array}$ & $\begin{array}{l}\text { Spiritual values and practices as } \\
\text { related to leadership } \\
\text { effectiveness; } \\
\text { Integrity viewed as the most } \\
\text { crucial spiritual value for success }\end{array}$ \\
\hline
\end{tabular}

Why do these values occur consistently within the literature? Because they embody what it is to be a spiritual human being in the workplace. They are the manifestation of the four components of spirituality in a person's lived experience. While there are many values listed above, a closer inspection reveals several key spiritual values expressed in varying ways. The first of these, integrity, is required to ensure a person is true to their RI and for others to be confident that such a person will act accordingly. Values such as honesty, openness, trustworthiness, humility are all captured within integrity. The second value is hope (gratitude, optimism, thankfulness, appreciation). Hope is what is desired and expected will happen. It is tied to faith which is "the conviction that a thing unproved by physical evidence is true" (Fry, 2003, p. 713). Individuals with hope/faith are prepared to persevere in the face of hardships to achieve their goals. Compassion is also a common value in much of the spirituality literature (Fry, 2003; Lips-Wiersma \& Nilakant, 2008; Solomon, 2002). Compassion refers to the promotion of the good of others. It addresses the concerns and vulnerabilities of others. Other values like benevolence, caring, empathy, love, forgiving, service, harmony, altruism can, broadly speaking, come under compassion. A spiritual person striving to overcome the egoistic self and connect with others encourages the development of these types of values. Spiritual people also value justice (Frohlich, 2001; Schneiders, 1989). Justice is the "constant and firm will to give to each what is due" (Mele, 2011, p. 122) and has strong links to charity and compassion of which justice is a duty. Values such as equality, fairness, respect, humanism, responsibility fall into this category. Finally, peace is an inner sense of completeness or wholeness. It ties strongly with hope/faith in that together they enable one to make sense of the world around them (Nelson, 2009).

Other values may be applicable here but such discussion is beyond the purview of this paper. What is clear is that a spiritual person is imbued with certain values. What is unclear, however, is how those values transition into ethical behaviours. After all, many people have the values listed above and do not demonstrate ethical behaviour in accordance with them. Further, many apparently "spiritual people" profess these values but they also fail to translate them into appropriate actions. How do these values become ethical outcomes within an organisational context?

\section{HOW ARE SPIRITUAL INDIVIDUALS IN THE WORKPLACE ETHICAL?}

A variety of studies demonstrates a clear link between values and workplace behaviour. People bring to work their values that drive behaviour (Roe \& Ester, 1999). These values are relatively stable over time and have an impact on attitudes and behaviour. Values affect one's perception of a situation, how one relates to others, and act as guides for choices and actions (Hitlin \& Piliavin, 2004).

The previous section has explored the RI of spiritual persons and how this acts as an overarching guide to what they value; specifically, what such persons value in a work context. Spiritual persons have internalised a certain conception of authentic excellence. This means that they not only intellectually adhere to specific values but also are committed to carrying them out. This section will explain the link between this RI and ethical behaviour using Aristotle's notion of virtue.

Virtues are attitudes, dispositions or character traits that enable us to be and to act in ways that allow us to pursue our human potential for moral excellence. They permeate our state of being and dispose us to action. The possessor of virtue is a morally good person. Virtue enables us to have the appropriate emotions and inner 
states as well as moving us to act in a virtuous way. Virtues develop through learning and practice. The road to becoming virtuous requires a person to be consistently motivated by moral goods in their actions. After a time of repeating such actions, they acquire good habits (Hursthouse, 2001).

However, virtues are not just habits. They are habits in that once acquired they become characteristic of a person. For example, a person who has developed the virtue of honesty is an honest person because he or she tends to be honest in all circumstances. Every virtuous act is more than a habit, as it requires choice, understanding and knowledge. The virtuous agent has come to recognise the value of virtue and view it as the appropriate response in a given situation. As Keenan (1995) has noted, "being virtuous is more than having a particular habit of acting...it means having a fundamental set of related virtues that enable a person to live and act morally well" (p. 714).

The link between value and virtue, and therefore spiritual and virtuous people, hinges upon the distinction between value and moral value. Mele (2005) distinguishes between moral values and values in general. Living according to moral values contributes to the good of the person (virtue) whereas making decisions based on other (non-moral) values does not affect our character or our goodness. Values guide all human decisions but a virtuous act is a special kind of act guided by moral values. We define a value (non-moral) as that which is worth having, getting or doing. In this sense it is relational, that is, it is a value for some person (Bond, 2001). A moral value (or good), on the other hand, when one lives according to it, leads to virtue and contributes to the perfection or flourishing of the individual as a human being. They are those things worth possessing if you want to become more human (Guardini, 1999). In this way, moral values are objective. For example, many people value success and fame but pursuit of these does not make one a better person in the Aristotelian sense. On the other hand, valuing and so striving to acquire courage, humility and honesty would make that person courageous, humble and honest, truly enriching their humanity and consequently making them a more attractive person.

The core values of spirituality are moral values to the extent that they resemble the objective moral goods of human nature. The nature of a spiritual person's RI is the assurance of this. Spiritual persons are not driven by their ego in the workplace. They seek wholesome relationships with others and a greater meaning in what they do. Adherence to their RI leads them to be others-focussed, which implies pursuing moral goods. The four formative components of the RI would hinder or discourage any value or habit that would smack of selfishness or egoism (i.e. vice).

Therefore, a spiritual person is likely to be virtuous and to demonstrate certain virtues. It is unclear why and how a spiritual person is necessarily ethical in the workplace. The theory that explains how this process might occur is Aristotelian virtue ethics. A virtuous person perceives that it is worthwhile to live according to moral values. A spiritual person's mindset is similar to that of a virtuous person. The spiritual values discussed earlier are moral values in that they are inherent, objective and contribute to the flourishing of human beings. Because they have internalised these values as part of their regulative ideal, spiritual people practise them as part of their daily living. In doing this, they become consistent habits aiming at the good for themselves and others, thereby entering the cycle of virtue acquisition and acquiring practical wisdom (see Figure 1). 


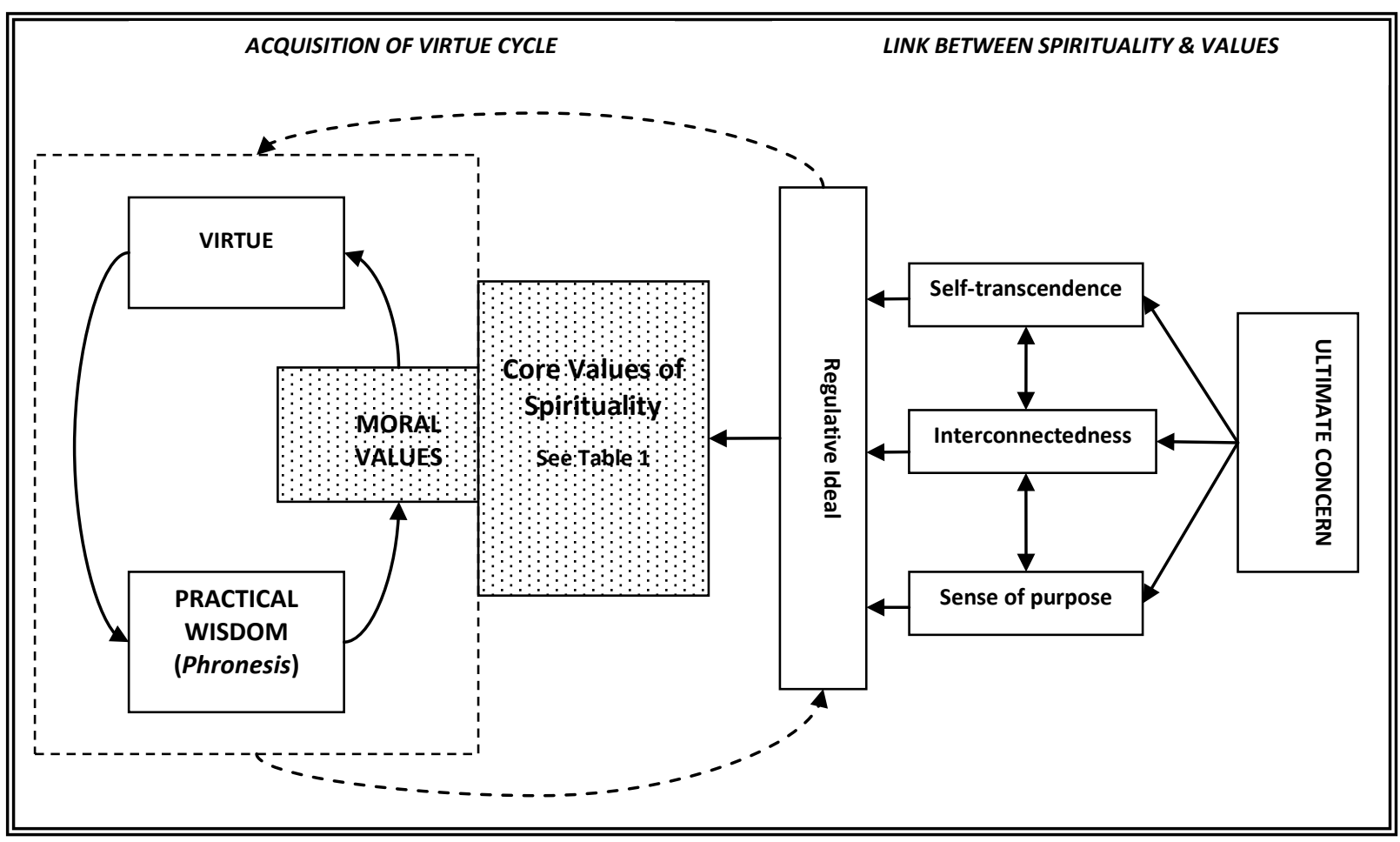

Figure 1: How Spirituality Translates into Ethical Behaviour

\section{WHAT ROLE DOES PHRONESIS PLAY IN THIS PROCESS?}

Phronesis or practical wisdom is an important element of Aristotelian virtue ethics. It is the ability to know specifically what one needs to do to live a virtuous life. Aristotle holds that a person's good character not only influences their actions but also their perception.

As Aristotle wrote:

The wise do not see things in the same way as those who look for personal advantage. The practically wise are those who understand what is truly worthwhile, truly important, and thereby truly advantageous in life: who know in short, that it is worthwhile to be virtuous. (Aristotle, Trans. 1941; 1144b31)

Aristotle believed that human beings were meant to live a virtuous life; that is, a 'good' life is a virtuous life. It is important to clarify how Aristotle understood the notion of 'good' and how it relates to virtue. He reasons as follows: when we say something performs well we mean it is fulfilling its purpose and the act or performance is 'good'; a knife is good if it cuts well. A defining feature of being human is rationality. Living in accordance with this capacity leads to a life of virtue and so a flourishing life or a eudaimonic life (Annas, 2006). Therefore, a virtuous life is a good life.

Thomistic-Aristotelians have developed Aristotle's theory of rationality further. They suggest that when one reasons about what to do (practical reason), one discovers a command to do good and avoid evil, with good perceived specifically as virtue. This is synderesis. Synderesis is the natural capacity or disposition of practical reason to apprehend intuitively these universal first principles of human action (Rhonheimer, 2008). Following this command of synderesis then, ultimately leads to flourishing. It is within reason itself that one discovers that one is called to be virtuous.

There is a common understanding of the meaning of phronesis in the literature (Arjoon, 2007; Bragues, 2006; Fowers, 2003; Kane \& Patapan, 2006; Maclntyre, 1999). Practical wisdom or prudence reflects the capacity to make wise decisions regarding which virtues are called for in particular situations and the best way to enact those virtues. Bragues (2006) has written about the importance of this in the business context. He explains how practical wisdom has the task of guiding action through the thickets of particularity. It overcomes the vagueness inherent in merely knowing that morally virtuous conduct is a mean between two extremes; it assists in pinpointing that mean in the situation at hand, taking into account all the relevant details and 
contingencies. As Aristotle stated, "The prudent individual consistently makes the right decisions to further every facet of a good life for himself, making sure to maintain their health, finances, social relationships and most importantly moral virtue" (Aristotle, Trans. 1941; 1140a24-b5).

Phronesis depends on the virtuous dispositions of the acting agent. Aristotle held that phronesis encompassed all the virtues, as it was impossible without a virtuous orientation. As Mele (2005) has noted:

Ethical perception depends on certain human capacities, related with character. This capacity to perceive the ethical dimension of the reality is no more than practical wisdom or prudence (in the moral sense), an intellectual virtue, which is the result of striving for virtue (p. 102).

This is because judgements about what to do are determined to some extent by how a person habitually acts. The more virtuous the agent is, the more clearly will a virtuous act be judged as a good thing to do. This is due to the intimate link between the human intelligence and will. For example, a virtuous person will judge honesty to be good whereas a non-virtuous person will not be so sure nor be so ready to live it.

The link between a virtuous character and phronesis is because the actions of the agent modify the agent. One's free actions have exterior, but more importantly, interior effects. Virtuous choices make a person more virtuous because human nature has a purpose or end; as has been seen, certain actions are not morally indifferent to that end and so either distance a person from or move a person closer to their proper end. Furthermore, Arjoon (2007) asserts that phronesis assists not only with judging well, but also in carrying out the judgement made; he calls phronesis 'a disposition to act'. He explains this as follows:

Philosophers have long realised the gap between knowledge (to know the good) and action (to do the good). It is precisely the virtues, in particular phronesis, that establish the link between knowing and doing; virtues regulate the dynamic interplay between knowledge and behaviour in concrete situations. Practical judgement entails having the right moral beliefs and the requisite knowledge to reach a decision in a concrete situation and to act on this disposition to do the right thing. (p. 235)

Maclntyre (1999) concurs on this point. He argues that practical judgment entails:

a chain of reasoning whose first premises concern the human good (goods that one desires, that would achieve human flourishing), whose intermediate steps specify what virtues require, if the human good is to be achieved, and whose conclusion is the action that is good and best for us to perform here and now. (p. 159)

Based on the above discussion, we argue that striving for virtue leads to growth in phronesis that in turn encourages further virtuous actions which leads to an increase in practical wisdom. This cycle is illustrated in Figure 1.

\section{PHRONESIS AND SPIRITUAL AGENTS AT WORK}

A virtuous person (through phronesis) perceives that it is worthwhile to live according to moral values and is disposed to live that way. A spiritual person's mindset is similar to that of a virtuous person. Their RI will enable them to live according to moral values, with respect to themselves and others; thereby entering the cycle of virtue acquisition and acquiring practical wisdom (see Figure 1).

The core values of spirituality are moral values to the extent that they resemble the objective moral goods of human nature. The nature of a spiritual person's RI is the assurance of this. This 'ideal' generates an embedded network of specific moral values that represents an 'internalised disposition' to act and be motivated in particular ways which address a spiritual individual's conception of what makes for excellence, in terms of their roles and responsibilities. The regulative ideal will provide a standard that informs judgement and helps to govern moral choices made in the context of daily working practice. It will be a reference point that will help to regulate both motivation and conduct so that a spiritual individual tends to conform to their internalised conception of good or excellent spirituality. To put this differently, motivations, decisions and actions that harmonise with a person's regulative ideal are appropriate and practised, while those that clash with it are rejected. Through repeated acts, these values become "inculcate[d] specific habits of the heart [i.e. virtues]" (Spohn, 1997, p. 3) which, in turn, contribute to the further development of one's spiritual character.

This person, because they have developed certain virtues, helped by phronesis, will know how and, want to act ethically, that is, do the right thing at work and elsewhere. Spiritual persons are not driven by their ego in the 
workplace. They seek wholesome relationships with others and a greater meaning in what they do. Adherence to their RI leads them to be others-focussed which implies pursuing moral goods. The four formative components of the RI would hinder or discourage any value or habit that would smack of selfishness or egoism (i.e. vice).

A spiritual person, even if lacking in virtue initially, will be assisted in valuing the moral goods because of their RI. This enables them to be more open to the promptings of human nature (synderesis). Therefore, as they live out their spirituality they acquire virtues and grow in practical wisdom. The moment they decide how to act, phronesis will confirm, encourage and guide them in living out their spirituality. Consequently, trying to live out one's spirituality facilitates the growth of practical wisdom that in turn confirms them in their RI.

What are the benefits of a spiritual employee/manager in the workplace? Authentically spiritual individuals exercise certain virtues. These virtues are the outward workings of an inward mindset (an internalised regulative ideal) and practice (phronesis). One would think that such an individual would provide their organisations with significant advantages as they exercise these virtues in their work context.

While the following research does not explicitly connect to the exercise of virtues, it does not take much imagination to see the potential linkages. For instance, why do spiritual individuals have greater organisational commitment (Milliman, Czaplewski \& Ferguson, 2003), increased job motivation (Jurkiewicz \& Giacalone, 2004), increased productivity (Duchon \& Plowman, 2005), and greater job satisfaction (Nur \& Organ, 2006)? Perhaps, at least partially, it is because they see work as a calling, not just a job; and it is a job in which they want to do the best they can, with humility and while respecting others, for example.

The spiritual individual's quest does not equate to an outward focus only; it also creates a desire to integrate the self. This internal focus leads to a number of outcomes that also indirectly benefit the organisation. It empowers individuals to achieve authentic spirituality, realize their virtuous ends and cope with and solve problems faced in life (Pargament, 1997; Silberman, 2003). Indeed, empirical evidence suggests that a spiritual life is likely to be characterised by positive satisfaction, a greater sense of fulfilment and a better quality of life (Dierendonck \& Mohan, 2006; Mohan, 2001; WHOQOL SRPB Group, 2006). The overall result of each of these factors is a happier, healthier and more fulfilled employee.

Finally, virtue, and its correlate phronesis, are also useful in recognising and minimising the potential problems of some inauthentic spiritualities (e.g. certain types of fundamentalism) since these are not directed at the good of others, do not resonate with an authentically spiritual regulative ideal and lead to practice of vice as opposed to virtue.

Peter McGhee is a senior lecturer in the Faculty of Business at Auckland University of Technology where he teaches Business Ethics and Organisational Behaviour. His research interests include spirituality in the workplace, virtue ethics and business and the interaction between business and society.

Patricia Grant is a senior lecturer in the Faculty of Business at Auckland University of Technology where she teaches Business Ethics, Sustainability and Law. Her research interests include spirituality in the workplace, virtue ethics, corporate governance and ethical leadership.

\section{REFERENCES}

Annas, J. (2006). Virtue ethics. In D. Copp (Ed.), The Oxford Handbook of Ethical Theory (pp. 515-536). Oxford: Oxford University Press.

Aristotle. (Trans. 1941). Nichomachean ethics. In R. McKeon (Ed.), The Basic Works of Aristotle. New York: Random House.

Arjoon, S. (2007). Reconciling situational social psychology with virtue ethics. International Journal of Management Review, 10(3), 221-243.

Ashforth, B. E., \& Pratt, M. G. (2003). Institutionalised spirituality: An oxymoron? In R. A. Giacalone \& C. L. Jurkiewicz (Eds.), Handbook of Workplace Spirituality \& Organizational Performance (pp. 93-107). Armonk, NY: M.E. Sharpe.

Ashmos, D. P., \& Duchon, D. (2000). Spirituality at work: A conceptualisation and measure. Journal of 
Management Inquiry, 9(2), 134-145.

Beazley, D., \& Gemmill, G. (2006). Spirituality \& entrepreneurship. Journal of Management, Spirituality \& Religion, 3(3), 258-270.

Benefiel, M. (2005). Soul at work. New York: Church Publishing.

Biberman, J., \& Whitty, M. (1997). A postmodern spiritual future for work. Journal of Organizational Change Management, 10(2), 130-138.

Bond, E. J. (2001). The concept of value. In L. C. Becker \& C. B. Becker (Eds.), Encyclopedia of Ethics. London: Routledge.

Bragues, G. (2006). Seek the good life, not money: The Aristotelian approach to business ethics. Journal of Business Ethics, 67(4), 341-357.

Cash, K. C., \& Gray, G. R. (2000). A framework for accommodating religion and spirituality in the workplace. Academy of Management Executive, 14(3), 124-134.

Cavanagh, G. F., \& Bandsuch, M. R. (2002). Virtue as a benchmark for spirituality in business. Journal of Business Ethics, 38, 109-117.

Dehler, G. E., \& Welsh, M. A. (1994). Spirituality and organizational transformation: Implications for the new management paradigm. Journal of Managerial Psychology, 9(6), 17-27.

Dierendonck, D., \& Mohan, K. (2006). Some thoughts on spirituality and eudaimonic well-being. Mental Health, Religion \& Culture, 9(3), 227-238.

Downey, M. (1997). Understanding Christian spirituality Mahwah, N.J.: Paulist Press.

Duchon, D., \& Plowman, D. A. (2005). Nurturing the spirit at work: Impact on work unit performance. The Leadership Quarterly, 16, 807-833.

Elkins, D. N., Hedstrom, L. J., Hughes, L. L., Leaf, J. A., \& Saunders, C. (1988). Toward a humanisticphenomenological spirituality: Definition, description and measurement. Journal of Humanistic Psychology, 28(4), 5-18.

Emmons, R. A. (2000). Is Spirituality an Intelligence? Motivation, Cognition and the Psychology of Ultimate Concern. The International Journal for the Psychology of Religion, 10(1), 3-26.

Fowers, B. (2003). Reason and human finitude: In praise of practical wisdom. American Behavioral Scientist, 47, 415-426.

Frohlich, M. (2001). Spiritual discipline, discipline of spirituality: Revisiting questions of definition and method. Spiritus, 1, 65-78.

Fry, L. W. (2003). Toward a Theory of Spiritual Leadership. The Leadership Quarterly, 14, 693-727.

Fry, L. W. (2005). Toward a theory of ethical and spiritual well-being, and corporate social responsibility through spiritual leadership. In R. A. Giacalone (Ed.), Positive Psychology in Business Ethics and Corporate Responsibility (pp. 47-83). New York: Information Age Publishing.

Giacalone, R. A., \& Jurkiewicz, C. L. (2003a). Right from wrong: The influence of spirituality on perceptions of unethical business activities. Journal of Business Ethics, 46, 85-97.

Giacalone, R. A., \& Jurkiewicz, C. L. (2003b). Toward a science of workplace spirituality. In R. A. Giacalone \& C. L. Jurkiewicz (Eds.), Handbook of Workplace Spirituality (pp. 3-28). Armonk, NY: M.E. Sharpe.

Giacalone, R. A., Paul, K., \& Jurkiewicz, C. L. (2005). A preliminary investigation into the role of positive psychology in consumer sensitivity to corporate social performance. Journal of Business Ethics, 58, 295-305.

Guardini, R. (1999). Lecciones en la Universidad de Munich. Madrid: BAC

Hitlin, S., \& Piliavin, J. A. (2004). Values: Reviving a dormant concept. Annual Review of Sociology, 30, 359-393.

Hursthouse, R. (2001). On virtue ethics. Oxford: Oxford University Press.

Jackson, K. T. (1999). Spirituality as a foundation for freedom and creative imagination in international business ethics. Journal of Business Ethics, 19(1), 61-70. 
Jurkiewicz, C. L., \& Giacalone, R. A. (2004). A values framework for measuring the impact of workplace spirituality on organizational performance. Journal of Business Ethics, 49, 129-142.

Kale, S. H. (2004). Spirituality, religion \& globalization. Journal of Macromarketing, 24(2), 92-107.

Kane, J., \& Patapan, H. (2006). In search of prudence: the hidden problem of managerial reform. Public Administration Review, September/October, 711-724.

Keenan, J. F. (1995). Proposing cardinal virtues. Theological Studies 56(4), 709-729.

Kolodinsky, R. W., Giacalone, R. A., \& Jurkiewicz, C. L. (2007). Workplace values and outcomes: Exploring personal, organisational and interactive workplace spirituality. Journal of Business Ethics, Unpublished.

Kriger, M. P., \& Hanson, B. J. (1999). A value-based paradigm for creating truly healthy organizations. Journal of Organizational Change Management, 12(4), 302-317.

Krishnakumar, S., \& Neck, C. P. (2002). The "what", "why" and "how" of spirituality in the workplace. Journal of Managerial Psychology, 17(3), 153-164.

Lapierre, L. L. (1994). A model for describing spirituality. Journal of Religion and Health, 33(3), 153-161.

Lips-Wiersma, M., \& Nilakant, V. (2008). Practical compassion: Toward a critical spiritual foundation for corporate responsibility. In J. Biberman \& L. Tischler (Eds.), Spirituality in Business: Theory, Practice, and Future Directions (pp. 51-72). New York: Palgrave Macmillan.

Maclntyre, A. (1999). Dependent rational animals: Why human beings need the virtues. Chicago: Open Court.

Macquarrie, J. (1992). Paths to spirituality (2nd ed.). Harrisberg, PA: Morehouse.

Marques, J. F. (2005). Spirituality in the workplace: Developing an integral model and a comprehensive definition. The Journal of the American Academy of Business, 7(1), 81-91.

Marques, J. F., Dhiman, S., \& King, R. K. (2007). Spirituality in the workplace: What it is, why it matters, how to make it work for you? Fawnskin, CA: Personhood Press.

Maslow, A. H. (1954). Motivation and personality. New York: Harper \& Row.

McGhee, P. K., \& Grant, P. (2008). Spirituality and ethical behaviour in the workplace: Wishful thinking or authentic reality? Electronic Journal of Business Ethics and Organization Studies, 13(2), 61-69.

Mele, D. (2005). Ethical education in accounting: Integrating rules, values and virtues. Journal of Business Ethics, 57, 97-109.

Mele, D. (2011). Catholic Social Teaching. In L. Bouckaert \& L. Zsolnai (Eds.), The Palgrave Handbook of Spirituality \& Business (pp. 118-128). London: Palgrave Macmillan.

Milliman, J. F., Czaplewski, A. J., \& Ferguson, J. (2003). Workplace spirituality and employee work attitudes: An exploratory empirical assessment. Journal of Organizational Change Management, 16(4), 426-447.

Mitroff, I. I., \& Denton, E. A. (1999). A spiritual audit of corporate America: A hard look at spirituality, religion and values in the workplace. San Francisco: Jossey-Bass.

Mohan, K. (2001). Spirituality and well-being: Overview. In C. Mattijs (Ed.), Integral Psychology (pp. 203-226). Pondicherry, India: Sri Aurobindo Asharam Press.

Neal, J., \& Biberman, J. (2003). Introduction: The leading edge in research on spirituality and organizations. Journal of organizational Change Management 16(4), 363-366.

Neck, C. P., \& Milliman, J. F. (1994). Thought self-leadership: Finding spiritual fulfillment in organizational life. Journal of Managerial Psychology, 9(6), 9-17.

Nelson, J. M. (2009). Psychology, religion and spirituality. New York: Springer Science+Business Media.

Nur, Y. A., \& Organ, D. W. (2006). Selected organizational outcome correlates of spirituality in the workplace. Psychological Reports, 98, 111-120.

Oakley, J., \& Cocking, D. (2001). Virtue ethics and professional Roles. Cambridge: Cambridge University Press. Pargament, K. I. (1997). The psychology of religion and coping. New York: Guilford. 
Reave, L. (2005). Spiritual values and practices related to leadership effectiveness. The Leadership Quarterly, $16,655-687$.

Rhonheimer, M. (2008). The perspective of the acting person: Essays in the renewal of Thomistic moral philosophy. Washington: Catholic University of America Press.

Roe, R. A., \& Ester, P. (1999). Values \& work: Empirical findings and theoretical perspectives. Applied Psychology: An International Review, 48(1), 1-21.

Sass, J. S. (2000). Characterizing organizational spirituality: An organizational communication culture approach. Communication Studies, 5(3), 195-217.

Schneiders, S. M. (1989). Spirituality in the academy. Theological Studies, 50, 676-696.

Silberman, I. (2003). Spiritual role modeling: The teaching of meaning systems. The International Journal for the Psychology of Religion, 13(3), 175-195.

Smith, J. A., \& Rayment, J. J. (2007). The global SMP fitness framework - A guide for leaders exploring the relevance of spirituality in the workplace. Management Decision, 45(2), 217-234.

Solomon, R. C. (2002). Spirituality for skeptics: The thoughtful love of life. Oxford: Oxford university Press.

Spohn, W. C. (1997). Spirituality and ethics: Exploring the connections. Theological Studies, 58(1), 109-124.

Tillich, P. (1952). The courage to be. New Haven: Yale University Press.

WHOQOL SRPB Group. (2006). A cross-cultural study of spirituality, religion, and personal beliefs as components of quality of life. Social Science \& Medicine, 62, 1486-1497.

Wink, P., \& Dillion, M. (2002). Spiritual development across the adult life course: Findings from a longitudinal study. Journal of Adult Development, 9, 79-94. 